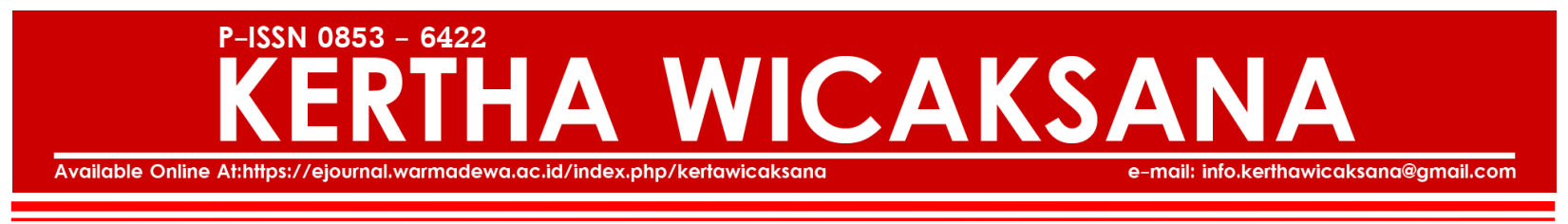

\title{
PERLINDUNGAN KAWASAN HUTAN WISATA BERBASIS ADAT DI DESA SANGEH
}

\author{
Ni Komang Sutrisni, I Made Hendra Wijaya \\ Fakultas Hukum Universitas Mahasaraswati \\ *Email : komang.sutrisni@yahoo.com
}

DOI: $10.22225 / K W \cdot 12.1 .416 .64-68$

Halaman: 64-68

\begin{abstract}
Abstrak
Objek dalam penelitian jurnal ini berlokasi di kawasan wisata alam Sangeh yang mana di dalamnya terdapat berbagai habitat fauna dan flora, fauna yang terbanyak adalah Kera abu-abu (Macaca fascicularis) kurang lebih 600 ekor dan flora pohon pala di kawasan hutan wisata alam sangeh. Perlindungan kawasan wisata alam sangeh melibatkan desa adat dalam melindungi dan mengelola kawasan wisata alam Sangeh, baik itu melindungi habitat monyet dan satwa lainnya maupun fauna yang ada di kawasan hutan wisata alam sangeh, perlindungan kawasan hutan wisata berbasis adat di desa sangeh dapat dilihat berupa bentuk kearifan lokal berbentuk bangunan suci (pura), maupun adanya Tri Hita Karana di dalam aturan adat, peran adat dalam melindungi kawasan hutan wisata sangeh dapat dilihat pada awig-awig desa adat Sangeh serta dibentuknya kelembagaan sadar wisata oleh desa adat sangeh untuk mengelola dan melindungi kawasan hutan wisata Sangeh.
\end{abstract}

\section{Kata Kunci: Perlindungan, Kawasan Hutan dan Desa Adat}

\begin{abstract}
Objects of this study is in the area of Natural Tourism Sangeh which in it there are various habitats of fauna and flora, the fauna is gray monkey (Macaca fascicularis) approximately 600 head and flora of nutmeg trees in the forest area of sangeh natural forest. Protection Sangeh natural tourism area involves indigenous villages in protecting and managing natural sangeh tourism area, whether it is protecting the habitat of monkeys and other animals and fauna that exist in natural forest sangeh forest, protection of custom-based tourism forest area in sangeh village can be seen in the form of wisdom local in the form of a sacred building (temple), or Tri Hita Karana in customary law, customary role in protecting forest area of sangeh can be seen in awig-awig of Sangeh custom village and the establishment of conscious tourism institution by adat Sangeh village to manage and protect Sangeh forest area.
\end{abstract}

\section{Keywords: Protection, Forest and Indigenous Villages}

\section{PENDAhuluan}

Pulau Bali merupakan sebuah pulau yang berada di wilayah Indonesia, dimana Pulau Bali juga merupakan salah satu destinasi terbaik wisata dunia yang memiliki berbagai macam atraksi wisata sebagai sebuah daya tarik baik itu bagi para wisatawan dunia maupun wisatawan lokal untuk datang ke Bali. Destinasi wisata yang ditawarkan kepada para pengunjung yang datang ke Bali sangatlah berbagai macam antraksi wisata yaitu keunikan Tradisi, agama, budaya, serta keindahan alamnya. Salah satu destinasi wisata yang sering dikunjungi oleh baik para wisatawan asing maupun wisatawan lokal adalah kawasan wisata alam
Sangeh yang berada di kabupaten Badung. Kawasan wisata alam sangeh sering dikunjungi oleh para wisatawan untuk melihat keberadaan habitat kera dan keindahan Hutan di kawasan wisata tersebut. Kawasan wisata alam sangeh juga sering digunakan sebagai tempat untuk sesi foto pre-wedding dan juga digunakan oleh warga setempat untuk melakukan upacara keagamaan.

Dalam pengelolaan kawasan wisata alam sangeh, sangat erat dengan kehadiran desa adat (Desa

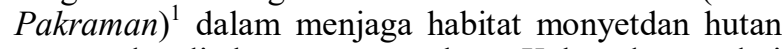
yang ada di kawasan tersebut. Keberadaaan dari kawasan hutan sangeh sudah ada sejak berabad-abad

1. Desa Pakraman yang selanjutnya disebut Desa adalah kesatuan masyarakat hukum adat di Provinsi Bali yang mempunyai satu kesatu an tradisi dan tata krama pergaulan hidup masyarakat umat Hindu secara turun temurun dalam ikatan Kahyangan Tiga atau Kahyangan Desa yang mempunyai wilayah tertentu dan harta kekayaan sendiri serta berhak mengurus rumah tangganya sendiri, lihat Pasal 1 ayat 4 Peraturan Daerah Propinsi Bali Nomor 3 tahun 2001 Tentang Desa Pakraman, lihat juga Pasal 1 ayat 5 Peraturan Daerah Propinsi Bali Nomor 3 Tahun 2017 Tentang Lembaga Perkreditan Desa 
yang lalu yang merupkan peninggalan kejayaan kerajaan Mengwi. Kemudian pada tahun 1993 Hutan di Desa adat sangeh ini berubah status menjadi Taman Wisata Alam (TWA) dengan diterbitkannya Surat keputusan Menteri Kehutanan Nomor: II/Kpts-II/1993 tanggal 16 Februari tahun 1993 dengan luas 13.969 Ha.

Berdasarkan buku data status Lingkungan Hidup Daerah Provinsi Bali Tahun $2010^{2}$ dan Laporan Status Lingkungan Hidup Daerah Provinsi Bali tahun 2015 tidak terjadi perubahan terhadap luas dari kawasan hutan wisata alam di Sangeh yaitu seluas 13,97 $\mathrm{Ha}$, yang terdiri dari 10,8 Ha hutan pala dan 3,169 $\mathrm{Ha}$ hutan tambahan. Di dalam brosur yang dikeluarkan oleh pengelolan Objek wisata Bukit Sari Sangeh, Desa adat Sangeh kecamatan Abiansemal, terdapat sejarah singkat terkait keberadaan kawasan wisata Sangeh yang tidak lepas dari keberadaan Pura Bukit Sari yang dibangun oleh Anak Agung Anglurah Made Karang Asem Sakti yaitu anak angkat dari Raja Mengwi Cokorda sakti Blambangan, dimana Pura Bukit Sari tersebut yang berada di tengah-tengah hutan Pala dibangun dikarenakan Anak Agung Anglurah Made Karang Asem Sakti melakukan tapa rare. Terkait kawasan tersebut dinamakan Sangeh dimana kata "Sangeh" memiliki 2 suku kata yaitu Sang dan ngeh, sang artinya orang dan Ngeh artinya melihat, jadi sangeh berarti orang melihat, dimana kata sangeh dikaitkan dengan mitologi masyarakat setempat bahwa pohon-pohon Pala yang ada di kawasan wisata alam sangeh dulunya berjalan dari Gunung Agung menuju ke suatu tempat di Bali barat, dikarenakan dalam perjalanan tersebut, tepat di kawasan wisata dangeh tersebut perjalanan pohon pala itu dilihat oleh manusia, maka pohon tersebut berada di daerah itu, dan daerah dimana pohon itu berhenti pada saat orang melihat disebut dengan nama Sangeh.

Di dalam kawasan wisata alam Sangeh terdapat beberapa satwa antara lain: Kera Abu-Abu (Macaca fascicularis) merupakan fauna yang banyak terdapat di Taman Wisata Alam Sangeh kurang lebih 600 ekor. Selain Kera Abu-Abu, jenis satwa seperti lain seperti Alap-alap Sapi (Falco moluccensis), Elang Brontok (Spizaetus cirrhatus), Elang Ular Bido (Spilornis cheela), Elang-alap Kawah (Falco peregrinus), Alapalap Capung, Burung Hantu (Pypte alba javanica), Merbah Cerucuk (Picnonotus gouvier), Musang (Paradoxurus hermaproditus), Kucing Hutan (Felis bengalensis), dan Sendang lawe (Ciconia episcopus). ${ }^{4}$ Selain flora di dalam hutan kawasan wisata di sangeh juga terdapat beberapa fauna antara lain: pohon Pala ( Difterocarpus Trinerfis, Amplas (Tetracera Scandens), Pule (Alstonia Scolaris), Buni (Antidema
Bunius), Cempaka Kuning (Michelia Champaka), Kepohpoh (Buchacananania Arboresncens) dan lain sebagainya. Selain fauna, di dalam kawasan wisata hutan sangeh juga terdapat berbagai jenis fauna.

Pelestarian kawasan wisata alam hutan sangeh yang melibatkan desa adat sangeh, tidak hanya pada keberadaan habitat monyet di kawasan tersebut, namun juga penting meneliti tentang perlindungan kawasan yang ada sekitar hutan wisata alam itu berada, seperti halnya bagaimana desa adat sangeh mengelola keberadaan kawasan wisata alam menjadi kawasan wisata dan kawasan religi, kemudian bagaimana peran adat (Desa Pakraman) memberikan sanksi bagi masyarakat yang melakukan perburuan dan perusakan hutan kawasan tersebut, selain itu juga terkait dengan keberadaan monyet-monyet tersebut perlu kiranya juga melihat bagaimana cara desa adat mengelola kawasan sungai dan perkebunan serta hubungan antara warga desa dengan habitat kera yang ada di kawasan wisata alam tersebut.

Berdasarkan pada latar belakang diatas, maka penulis memeberikan beberapa rumusan masalah sebagai berikut:

A. Bagaimana kearifan lokal dari sangeh tersebut dapat melindungi kawasan wisata alam Sangeh?

B. Bagaimana peran adat dalam mengelola keberadaan kawasan alam sangeh untuk kepentingan masyarakat?

\section{PEMBAHASAN}

\section{A. Perlindungan Kawasan Wisata Alam Sangeh Melalui Kearifan Lokal}

Sangeh merupakan sebuah desa yang memiliki kawasan wisata berupa Hutan yang terdiri dari berbagai jenis flora dan fauna. Kawasan hutan tersebut juga sangat berperan penting dalam menunjang kehidupan kehidupan masyarakat desa Sangeh, sehingga kawasan hutan tersebut sangat dijaga dan dilindungi keberadaannya oleh masyarakat desa Sangeh. Disisi lain kearifan lokal masyarakat setempat juga sangat berperan penting dalam menjaga dan melindungi keberadaan kawasan hutan wisata sangeh yaitu dengan adanya beberapa tempat suci di beberapa titik di kawasan hutan sangeh tersebut yang menjadikan tempat tersebut harus dilindungi kesuciannya berdasarkan keyakinan masyarakat desa sangeh. Masyarakat Desa Sangeh memiliki keyakinan yang penuh terhadap perlindungan kawasan sangeh dari aspek relegius magis yang ditandai dengan adanya beberapa tempat suci (pura) ${ }^{5}$ di beberapa titik kawasan

2. Provinsi Bali,2010, Buku Data Status Lingkungan Hidup Daerah Provinsi Bali Tahun 2010, h.I-5

3. Provinsi Bali, 2015, Laporan Status lingkungan hidup daerah Provinsi bali Tahun 2015, h.2-5

4. Ibid

5. Pura adalah tempat ibadah umat Hindu. Selain sebagai sarana Ibadah, Pura juga sebagai pusat berbagai kegiatan umat Hindu seperti bidang pendidikan, seni budaya, sosial kemasyarakatan, persembahyangan serta tempat untuk sosialisasi berbagai informasi baik dari tokoh masyarakat, tokoh agama, dan institusi Pemerintah. Lihat, Ni Made Jendri, 2012, Perilaku Hidup Bersih dan Sehat (PHBS) di Pura, Parisada Hindu Dharma Indonesia dan Kementerian Kesehatan Republik Indonesia, Bali h. 6 
hutan sangeh yang pada waktu-waktu tertentu diselenggarakan upacara-upacara (piodalan) ${ }^{6}$ sebagai wujud bakti terhadap keyakinan adanya unsur-unsur magis yang berperan menjaga kelangsungan atau kelestarian kawasan hutan Sangeh.

Tempat-tempat suci yang berada di kawasan tersebut antara lain :

1. Pura Bukit Sari yang berada di tengah-tengah hutan kawasan wisata sangeh, dimana keberadaan Pura Bukit Sari merupakan sebuah tempat suci yang dibangun pada abad ke 17 yang merupakan peninggalan kerajaan Mengwi di Bali.

2. Pura Melanting yang terdapat di bagian tengah kawasan hutan Sangeh kurang lebih 200 meter dari Pura Bukit Sari, pura Melanting merupakan sebuah tempat suci (pura) yang diyakini sebagai tempat sujud kepada wujud tuhan sebagai Dewi Melanting yang memiliki fungsi sebagai penguasa alam gaib di kawasan hutan sangeh serta diyakini oleh masyarakat desa sangeh sebagai pelindung atau pengayom bagi para pedagang dan memberikan keselamatan warga masyarakat desa Sangeh. Komplek pura Melanting terdiri dari beberapa bangunan berupa Meru ${ }^{7}$ Tingkat Tiga.

3. Pura Tirta yang terdapat dikawasan Hutan Sangeh merupakan sebuah tempat suci (Pura) yang berada di sebelah sisi timur kawasan wisata hutan sangeh dekat dengan jalan utama Denpasar -Plaga, dimanaPura tirta ini terdiri dari satu pelinggih yang berbentuk Tugu

4. Pura Anyar juga terdapat di kawasan hutan Sangeh merupakan sebuah tempat suci (Pura) yang berada di sebelah sisi tenggara kawasan wisata hutan sangeh dekat dengan jalan utama Denpasar -Plaga yang merupakan Pengembangan dari Pura Batan Pule yang terletak di bawah pohon Pule

5. Pohon Lanang Wadon, sebuah Pohon yang berada di sisi sebelah Timur kawasan hutan sangeh, dimana bentuk dari pohon Lanang Wadon menyerupai alat kelamin laki-Laki dan Perempuan yang mana Lanang berarti laki-laki dan Wadon berarti Wanita

6. Pura Beji yaitu Sebuah tempat suci yang

difungsikan sebagai tempat pembersihan
(pengelukatan) bagi warga masyarakat pada umumnya dan masyarakat desa sangeh pada khususnya yang berlokasi di sebelah barat kawasan hutan sangeh yakni Tukad Yeh Penet.

7. Pohon Pala, merupakan pohon yang tumbuh di kawasan hutan sangeh yang menurut kepercayaan masyarakat setempat pohon tersebut tidak dapat tumbuh dan berkembang ditempat lain. Hasil atau Buah yang dihasilkan dari pohon pala tidak boleh di ambil sembarangan dikarenakan adanya kepercayaan terhadap keberadaan bentuk kutukan apabila mengambil buah pala. Menurut pengelola taman wisata sangeh terkait adanya pohon pala, pada awal Januari 2010 terdapat sebuah pohon pala yang tua dan akan roboh dan diperkirakan akan roboh kearah bangunan utama Pura Bukit Sari namun pohon tersebut tidak ada yang berani menebang dikarenakan masyarakat takut akan mendapat kutukan, namun pada akhirnya pohon tersebut roboh dengan sendirinya kearah barat daya persis antara bangunan Bale Kulkul dan Pawaregan, sehingga hanya menimbulkan sedikit kerusakan hanya pada tembok luar pewaregan saja.

Dari beberapa uraian keberadaan tempat-tempat suci (pura) dikawasan hutan Sangeh tersebut dengan beraneka fungsi dari tempat-tempat suci tersebut yang diyakini oleh warga masyarakat desa Sangeh sebagai penjaga kawasan hutan Sangeh untuk upaya pelestarian dan perlindungan habitat kawasan hutan Sangeh. Selain tempat-tempat suci tersebut sebagai perwujudan kearifan lokal masyarakat desa sangeh, kearifan lokal yang sangat erat dengan kehidupan masyarakat adat desa sangeh yaitu Tri Hita Karana. ${ }^{8}$ Dalam Purwaning Atur dijelaskan bahwa bahwa desa sangeh berdasarkan pada Tri Hita karana yaitu:

6. Piodalan adalah peringatan, hari suci atau hari jadi suatu pura atau bangunan suci bagi umat Hindu di Bali, yang salah satu bentu upacara - upacara di Bali yang dilakukan pada waktu-waktu yang telah ditentukan atau berkala yang merupakan suatu mata rantai yang tidak dapat dipisahkan antara Tatwa/ filsafat yang merupakan tujuan dari ajaran agama Hindu, serta susila yang merupakan aturan-aturan yang patut dilaksanakan untuk mencapai tujuan, S. Swarsi,2003, Upacara Piodalan Alit di Sanggah/Merajan.Paramita, Surabaya. h 1-6

7. Meru adalah salah satu jenis tempat pemujaan untuk Istadewata, bhatara- bhatari yang melambangkan gunung Mahameru. Landasan filosofis dan meru adalah berlatar belakang pada anggapan adanya gunung suci sebagai stana para dewa dan roh suci leluhur. Untuk kepentingan pemujaan akhirnya gunung suci itu dibuatkan berbentuk replika (tiruan) berbentuk bangunan yang dinamai candi, prasada dan meru, lihat, Babad Bali, 2000 Tinjauan Filosofis dan Fungsi Meru, available at cited at http://www.babadbali.com/canangsari/hkt-merufungsi.htm, diakses pada tanggal 10 november 2017

8. Konsep kosmologi TRI HITA KARANA (Tri = tiga, Hita = sejahtera, Karana = penyebab) merupakan falsafah menekankan tiga hubungan manusia dalam kehidupan di dunia ini. Di dalam Bhagavad-Gita III.10 yang merupakan unsur dari Tri Hita Karana menyebutkan Sahayajnah prajah sristwa pura waca prajapatih anena prasawisya dhiwan esa wo'stiwistah kamadhuk, yang artinya adalah Pada jaman dahulu Prajapati menciptakan manusia dengan yadnya dan bersabda: dengan ini engkau akan berkembang dan akan menjadi kamadhuk dari keinginanmu. Meskipun dalam kitab tersebut tidak bernama Tri Hita Karana, dalam kitab tersebut dinyatakan Tuhan (Prajapati) telah beryadnya menciptakan alam semesta dengan segala isinya. Karena iti manusia (Praja) hendaknya beryadnya kepada Tuhan (Prajapati), kepada sesama manusia (Praja) dan kepada lingkungannya (Kamadhuk), lihat Yayasan Bali Galang, 2000, TAFSIR AGAMA HINDu, available Cited at: http://www.babadbali.com/canangsari/trihitakarana.htm, diakses pada tanggal 11 November 2017 
1. Parhyangan; genah sane kanggehang suci olih krama desa maka genah ngarcana Hyang Widhi, saha maka jiwatman desane

2. Pawongan; Krama desa adat sami, pawakan Trikaya, sane ngajegang prayojananing kauripan

3. Palemahan; Genah krama desa adat, sumujub rawuh pratisentananiya riwekas, sane mapiteges angga sasrira

Sehingga dalam melindungi kawasan hutan wisata sangeh, keafiran lokal Tri Hita Karana ini mempertegas desa adat sangeh dalam melaksanankan perlindungannya terhadap hutan dan lingkungan di wilayah desa adat sangeh dalam kaitannya keberadaannya Pelamehan yang terdapat dalam awigawig desa adat sangeh. Dari adanya kearifa lokas baik yang berada di kawasan hutan wisata sangeh yang berupa bangunan suci (pura) maupun keberadaan Tri Hita Karana dapat menunjukan bahwa dapat mempengaruhi prilaku masyarakat dalam hal pentingnya melindungi dan menjaga kawasan hutan Sangeh sebagai bentuk wujud nyata yang bersumber dari keyakinanan masyarakat Sangeh, selain itu kearifan lokal juga dapat dipandang sebagai penyangga utama dalam memberikan perlindungan terhadap keberadaan kawasan wisata hutan sangeh.

\section{B. Peran Adat Dalam Mengelola Keberadaan Kawasan Alam Sangeh Untuk Kepentingan Masyarakat}

Selain keberadaan local geinus atau kearifan local yang terdapat dalam masyarakat desa Sangeh Baik berupa keberadaan tempat-tempat suci (Pura) sebagai wujud nyata kearifan lokal kawasan wisata alam sangeh. Peran adat juga sangat berperan penting untuk melindungi kawasan hutan Sangeh dengan wujud pengelolaan kawasan alam Sangeh. Salah satu bentuk perlindungan adat dalam hal keberadaan kawasan alam Sangeh dapat dilihat pada kesadaran masyarakat adat Sangeh yang menuangkan perlindungannya terhadap kawasan hutan Sangeh melalui hukum adatnya yaitu berupa awig-awig. Dalam pawos 47 awig-awig desa pakraman Sangeh menyatakan:

Kuluwarga Desa Adat Sangeh Tan Kengi Ngusak Asik Ring Sejeroning Alas Menakadi Ngambil Taru, Rencek, Buah Pala, Menyan Lan Sane Siosan Sedurung Polih Pamutus Saking Prajuru Desa adat Sangeh (dalam terjemahan umum: keluarga desa Adat Sangeh tidak diperbolehkan merusak hal yang terkait dengan hutan seperti mengambil Pohon, Ranting, Buah Pala, Menyan, dan yang lain-lainsebelum mendapatkan persetujuan Pengurus Desa Adat Sangeh)

Selain mengacu pada aturan adat Desa Sangeh yang berupa awig-awig, dalam perlindungan kawasan hutan Sangeh juga mengacu pada peraturan nasional yaitu Undang-Undang 41 tahun 1999 Tentang Kehutanan, karena didalam Pasal 34 dan 67 Undang-Undang 41 tahun 1999 Tentang Kehutanan, negara juga memberikan kewenangan kepada masyarakat hukum adat untuk mengelola kawasan hutan. Selain UndangUndang 41 tahun 1999 Tentang Kehutanan, desa adat sangeh dalam melindungin kawsan hutan Sangeh juga mengacu pada Undang-Undang 18 tahun 2013 Tentang Pencegahan dan Pengerusakan Hutan.

Aturan yang dibuat oleh Desa adat Sangeh yang berupa awig-awig sangat dihormati oleh masyarakart Desa Adat Sangeh karena aturan adat (awig-awig) tersebut mengikat baik secara personal maupun secara keyakinan yang hal tersebut tentusaja dapat langsung menyentuh keberadaan masyarakat adat di desa sangeh, serta dalam awig-awig juga terdapat pengaturan sanksi yang sangat tegas, yaitu salah satunya sanksi yang mengatur terhadap keberadaan kawasan hutan Sangeh yaitu: Yening wenten Kuluwarga Sane mamurung Awig-Awig Desa Adat Sangeh kadanda antuk jinah bolong asli 200 kepeng. ( dalam terjemahan umum: Jika ada keluarga yang melanggar aturan dari awig-awig Desa Adat Sangeh dikenakan denda berupa uang asli 200 kepeng). Berdasarkan wawancara kepada Bendesa Adat Sangeh Ida Bagus Dipayana, pada tanggal 16 Oktober 2017 di Desa Sangeh, dimana beliau menyatakan bahwa apabila terjadi pelanggaran di kawasan hutan di sangeh, maka masyarakat tersebut dikenakan sanksi berupa bentuk pengembalian keseimbangan secara niskala, dengan cara melakukan ritual-ritual adat yaitu upacara pembersihan secara niskala (mecaru) di wilayah areal kawasan wisata hutan sangeh dan di pura Bukit Sari sangeh.

Perlindungan kawasan hutan sangeh yang dilakukan desa adat Sangeh selain membentuk aturan adat juga dilakukan dengan cara membentuk sebuah organisasi yaitu sebuah kelompok Sadar Wisata Bukit Sari Sangeh, dimana kelompok tersebut yang terdiri dari beberapa anggota yang diambil dari setiap 5 Banjar/ Dusun yang ada di wilayah desa Adat Sangeh, dari masing-masing Banjar hanya diambil 3 orang saya untuk menjadi pengurus Sadar Wisata Bukit Sari Sangeh, jadi dari total 5 banjar tersebut terdapat 15 orang yang tergabung dalam Sadar Wisata Bukit Sari Sangeh untuk mengurusi kegiatan dan keamanan kawasan hutan wisata alam Sangeh.

Kelompok Sadar Wisata Bukit Sari Sangeh yang bertugas mengurusi kawasan hutan sangeh berada di bawah kewenangan Desa adat sangeh dan diawasi oleh Bendesa Adat Sangeh. Salah satu tugas dari Sadar Wisata Bukit Sari Sangeh selain bertugas melindungi kawasan hutan sangeh juga bertugas dalam hal pengelolaan wisata serta pengelolaan hasil yang diperoleh dari hasil kawasan wisata hutan Sangeh, dimana dalam pengelolaan hasil tersebut baik itu dari

9. Awig-awig yang berasal dari kata wig yang artinya rusak, sedangkan awig berarti tidak rusak atau baik. Awig-awig adalah aturan yang dibuat oleh krama desa pakraman atau krama pakraman yang dipakai sebagai pedoman dalam pelaksanaan Tri Hita Karana sesuai dengan desa mewacara dharma agama di desa Pakraman/banjar pakraman masing-masing, lihat I Ketut Wiana., 2004, Bagaimana Umat Hindu Menghayati Tuhan. Jakarta: Pustaka Manik Geni.h 141 
pemasukan tiket menuju kawasan hutan Sangeh yang terdiri dari tiket masuk masuk domestic, internasional, praweding dan lain-lain, juga hasil yang terdapat dari penyewaan tempat kios-kios yang diperuntukan hanya bagi warga desa adat sangeh yang hasilnya dipergunakan untuk kepentingan upacara- upacara adat di desa Sabngeh secar menggunakan system subsidi, selain itu juga hasil yang diperoleh dari kawasan wisata hutan sangeh dipergunakan untuk pembiayaan pengelolaan kawasan hutan sangeh dan pembaayaran gaji bagi anggota kelompok Sadar Wisata Bukit Sari Sangeh.

\section{SIMPULAN}

Perlindungan kawasan wisata alam sangeh melalui kearifan lokal dapat dilihat dalam bentuk keyakinan masyarakat dengan beberpa tempat suci di kawasan wisata alam Sangeh yang membuat masyarakat sangeh percaya dengan adanya kekuatan-kekuatan niskala (tidak ampak) yang ikut juga menjaga kelestarian kawasan hutan sangeh. Kearifan lokal tersebut di manifestasikan atau diwujudkan dalam bentuk adanya beberapa pura (tempat suci/pemujaan) sebagai tempat untuk melakukan upacara-upacara suci atau keagamaan terhadap manifestasi Ida Sang Hyang Widhi Wasa sebagai wujud rasa bakti warga masyarakat desa adat sangeh untuk menjaga kelestarian kawasan hutan sangeh serta adanya kearifan lokal Tri Hita Karana yang membuat keyakinan masyarakat adat sangeh lebih melindungi kawasan wisata alam sangeh.

Peran Adat Dalam Mengelola Keberadaan Kawasan Alam Sangeh Untuk Kepentingan Masyarakat yaitu dengan cara membuat aturan desa adat yang berupa awig-awig yang bersinergi dengan hukum nasional serta kesadaran masyarakat adat dengan membentuk sebuah lembaga pengelolaan dengan nama Kelompok Sadar Wisata Bukit Sari Sangeh yang bertugas mengurusi kawasan hutan sangeh berada di bawah kewenangan Desa adat sangeh dan diawasi oleh Bendesa Adat Sangeh. yang memiliki tugas melindungi kawasan hutan sangeh dan juga bertugas dalam hal pengelolaan wisata serta pengelolaan hasil yang diperoleh dari hasil kawasan wisata hutan Sangeh.

\section{DAFTAR PUSTAKA}

I Ketut Wiana., 2004, Bagaimana Umat Hindu Menghayati Tuhan. Jakarta: Pustaka Manik Geni.h 141

Ni Made Jendri, 2012, Perilaku Hidup Bersih dan Sehat (PHBS) di Pura, Parisada Hindu Dharma Indonesia dan Kementerian Kesehatan Republik Indonesia, Bali

Provinsi Bali,2010, Buku Data Status Lingkungan Hidup Daerah Provinsi Bali Tahun 2010,

Provinsi Bali, 2015, Laporan Status lingkungan hidup daerah Provinsi Bali Tahun 2015

S. Swarsi,2003, Upacara Piodalan Alit di Sanggah/ Merajan.Paramita, Surabaya.

Peraturan Daerah Propinsi Bali Nomor 3 tahun 2001 Tentang Desa Pakraman, lihat

Peraturan Daerah Propinsi Bali Nomor 3 Tahun 2017 Tentang Lembaga Perkreditan Desa

Undang-Undang 41 tahun 1999 Tentang Kehutanan,

Undang-Undang 18 tahun 2013 Tentang Pencegahan dan Pengerusakan Hutan. 